\title{
MOTIVATION THROUGH INTERACTION: A QUESTIONAIRE STUDY OF TURKISH PRE-SERVICE EFL TEACHERS
}

\author{
Mehmet Çelik
}

\begin{abstract}
To sustain interest and provide motivation with the young adult learners of English as a second/foreign language at tertiary classroom settings, this paper argues for the inclusion of one teacher-specific motivation factor, namely, INTERACTION. A questionnaire comprising 15 item statements to elicit learners' views on the efficacy of interaction was administered to 363 participants with an age range of 18-24. Findings indicate, in general, that the phenomenon of interaction is favored as a device for motivation. Certain psychological dimensions are identified for interaction factor. Identifying and quantifying this factor within the teacher-specific motivational area as conceptualized by Dörnyei (1994), the paper finally suggests that appropriately higher level of interaction between teachers and students positively contribute to foreign language learning in varying degrees.
\end{abstract}

Keywords: foreign language learning, in-class interaction, motivation, young adult learners, teacher-specific.

\section{ETKILLESIM YOLUYLA GÜDÜLEME: INGILIZCCE YABANCI DIL ÖGRETMEN ADAYLARI ÜZERINE BİR ANKET ÇALIŞMASI \\ $\ddot{O}_{z e t}$}

Bu makale, Ingilizceyi yabancı veya ikinci dil olarak öğrenen genç yetişkin (üniversite) ögrencilerin sinıf ortamındaki güdülemesini sağlamak ve ilgiyi devamlı kılabilmek amacıyla, ETKILESSIM olarak adlandırılan ögretmen kaynaklı güdüleme faktörünün mevcut güdüleme literatürüne dahil edilmesi gerektiğini savunur. Etkileşimin yararları üzerine öğrenci görüşlerini ortaya çıkaran 15 maddelik bir anket, 18-24 yaşları arasındaki 363 deneğe uygulanmıştır. Bulgular, etkileşim olgusunun güdülemeye yardımcı bir araç olarak kabul gördügünü öne sürer. Etkileşim faktörünü açıklamak amacıyla belirli psikolojik boyutlar ortaya konmuştur. Makalenin öne sürdügü tartışma, bu faktörün Dörnyei (1994) tarafindan öngörülen ögretmen kaynakl güdüleme alanına dahil edilip, istatistiksel olarak değerlenirilmesinden sonra, ögretmen ve öğrenciler arasinda uygun olarak gelişen yüksek seviyedeki etkileşimin, değişik düzeylerde yabancı dil ögrenimine olumlu katklları olduğudur.

Anahtar sözcükler: yabancı dil öğrenimi, sınıf içi etkileşim, güdüleme, genç yetişkin öğrenciler, öğretmen kaynakl. 


\section{Introduction}

The importance of motivation in second/foreign language (L2) learning is being increasingly noted in the last three decades. With the publishing of Gardner and Lambert (1972) came a surge in interest on the role of motivation in this area. Numerous studies (e.g. Svanes 1987; Gardner 1985; Dörnyei 1990; Clement, Dörnyei and Noels 1994) helped establish the commonplace terms such as integrative, instrumental, intrinsic, and extrinsic motivation. Such studies consider the motivation from social-psychological orientations in which attitudes play a significant role as affective variables of second language proficiency and behavior. Although Gardner's social psychological model was well-grounded in scientific terms, it was not sufficiently broad to include '... a more pragmatic, educationcentered approach to motivation, which would be consistent with the perceptions of the practicing teacher and which would also be in line with the current results of mainstream educational psychological research' (Dörnyei 1994:273). Several studies, such as Crookes and Schmidt (1991), Oxford and Shearin (1994) and Dörnyei (1994) emphasized the need for a construct that also utilizes a more classroom-focused motivational framework with practical instructional implications.

Crookes \& Schmidt (1991:502) called for a model of motivation that is '... congruent with the concept of motivation that teachers are convinced are critical for SL learners'. Clement et al. (1994:423) note the importance of the relevance of classroom related factors. They found that teacher's style, competence, rapport, self-confidence, classroom atmosphere and group cohesion are important contributors to motivation. Research shows that situation-specific factors significantly contribute to L2 motivation in the foreign language classroom (Julkunen 1989). Clement et al. (1994:418) further note that 'Increasing the classroom relevance of the motivation research is certainly a worthwhile objective.' Therefore, concepts such as environment in class, empathy of teachers, making the subject matter interesting, the feeling of belonging to a group, group cohesion, appropriate methods, presentation skills, and so on become significant factors influencing motivation in classroom. Furthermore, as stressed by Prabhu (1992:225), 'A change in classroom routines can be productive of learning only to the extent it is motivated and sustained by conceptual exploration by the teachers themselves.'

Dörnyei's (1994) conception of motivation is more classroom-based. Part of his framework rests on The Learning Situation Level, which is associated with situation specific factors entrenched in various aspects of L2 learning within a classroom setting. It has three components: 1) Course-specific, 2) Group-specific, 
and 3) Teacher-specific. The first one is related to syllabus, teaching materials, teaching method, and so on. The second one takes into account various characteristics of the learner group. The last one considers the motivational impact of the teacher's personality, behavior, teaching style and practices. Besides, the following features are important: a) empathy, congruence, acceptance, b) role of a facilitator, c) interest and enthusiasm, and d) taking students' learning seriously. In order to broaden the motivational devices in a tertiary setting, following Dörnyei (1994), this study investigates quantitatively what may be called teacher-specific variable: interaction. This variable, which can be part of a humanistic approach in foreign language classes, falls largely within the framework of teacher-specific motivational components as conceptualized by Dörnyei (1994).

This study examines the endorsement levels of statements by pre-service teachers in terms of the optimum level of interaction and tries to establish several scales underlying psychological dimensions. The notion of interaction as it is taken in this study covers many of the concepts discussed by Dörnyei (1994). Before going on to describe the methodology of the study, we now turn to examining what is meant, in this study, by interaction.

\section{Interaction}

One of the most important features of a language classroom is that the lesson is an arena of human interaction with different personalities, motives, and expectations at play. The learning atmosphere, emotional climate, group cohesion, and enjoyment of being in the group are fundamental issues for motivation. In order to achieve an interactive atmosphere, '... we need an ambiance and relations among individuals that promote a desire for interaction' (Rivers 1987:9). Further, Rivers (1987:109) note that 'Interaction is ... an affective, temperamental matter, not merely a question of someone saying something to someone', stressing the importance of converting the classroom into real life-like contexts where what is done in the classroom is as genuine as possible. For instance, Morgan (1997) achieved a high level of motivation in the teaching of intonation by bringing in the learners' social and cultural attitudes.

The teacher may have to adopt a more interactive approach in the classroom. For instance, according to Prodromou (1991), in the context of Greece, a good teacher, among other qualities, is someone who is friendly, 'one' of the students, and genuine in dialogues. She tries to communicate, believes in students, makes students believe in themselves, asks for student opinions, does the lesson together, talks about her life, and knows how to treat someone who sits at a desk for six hours. In his longitudinal study of motivation of British learners of German aged from 11 and 17, Chambers (1999) too found that the teacher factor is a lot more 
important than the learning environment, access to equipment, the textbook, etc. in the positive or negative evaluation of a subject: 'The teaching methodology, the textbook, the computers available count for little if the teacher-pupil relationship is lacking' (p.152).

Prabhu (1992:225) elaborates by noting that behind the ritualistic, routinized aspect of lessons giving a certain role to the teacher and another to the students are a group of learners with different personalities, aspirations, motives, all of which make the classroom a real arena for human interaction. Then it is best to transform a classroom into more of a small community group in which the teacher and students behave more like the way they do outside classroom. The teacher should never lose sight of the make-up of the classroom population. Recognizing the differences and the importance of interaction, she can make the classroom a real learning ground with certain uncurricular attitudes, techniques and motivationraising acts and tasks.

In line with these studies that informed the present investigation, the author tried to utilize an interactive approach, which lasted for 14 weeks, in which teacher-student relationship is optimized for a better learning environment. In order to promote a desire for interaction that would result in better learning, the author tried to create a caring and genuine atmosphere where the communication resembled more like what goes on outside the classroom, considering the learners' needs and characteristics, changing the routine of teaching sequences, and so on (see the appendix). Therefore, the purpose of the study is to reveal student attitudes and expectations regarding the nature if interaction between students and teachers so as to inform colleagues as to the optimum level of interaction in the classroom setting.

\section{The study}

The participants, pre-service teachers of English, were 363 (96 males; 267 females) students, all enrolled at Hacettepe University. Prior to tertiary education, they had been learning English as a foreign language for 6 years. 135 of them were in the 1st year, 79 in the 2nd, 96 in the 3rd and the remaining 53 were in their final 4 th year. The ages of participants range from 18 to 24 , so they can be labeled as young adults. These students were chosen for this study because 1) they were learners of English (upper-intermediate and advanced depending on what year they are) as well as pre-service teachers, 2) they are representative of other students (about ten thousand) in the same departments across the country in that all gain entry to these departments through a central placement test, and most importantly 3) they were subjected to a teaching method that involved Interaction. 
This study can be regarded as experimental in that participants were subjected to a methodology that vigorously employed features of teacher-specific motivation. The points related to teacher effect, and more importantly the items employed in questionnaire, were applied in the classroom. So when the participants were asked to judge the acceptability or suitability of items for their own learning process, the questionnaire tried to elicit informed knowledge as well as conscious judgments of participants.

Beforehand though, in developing the items, student views had been sought: they were asked to write freely and anonymously what is good and bad about the types of interactions the author had with students. Views regarding the type and nature of interactions were reflected in the wording of questionnaire items. The questionnaire thus assembled was piloted to 30 students, 23 female and 7 male, in May 2002, to avoid pitfall in instruction and administration procedures as well as the comprehension of the item statements. Based on the feedback received and observations, instructions and the wording of the items were revised to ensure that participants would understand what they were required to do with regard to the scales and that language of the items clearly reflected the ideas contained in them.

In the questionnaire, 15 items outlined the level of intimacy, intensity, or proximity of the educational interaction between the students and the teacher/lecturer. Participants were asked to indicate the extent to which they agreed or disagreed with the statements on a 5-point Likert type scale. The minimum response score on this scale is 1, meaning Strongly Agree while the maximum score is 5, meaning Strongly Disagree. The lower the mean, the more endorsement an item receives. The 15 items, some of which were adapted from Prodromou's (1991) qualitative study results, were used to assess students' attitude towards the student-teacher interaction in a way it idealizes real life, going beyond the boundary of classroom atmosphere.

\section{Research questions}

The research attempts to answer important questions as far as the teaching/learning relationship is concerned between teachers/lecturers at tertiary institutions where the personal proximity between each party is expected to be the loosest of all.

What is the attitude of tertiary students towards a more intensive/genuine interaction between learners and teachers? What is the optimum level of interaction between the teacher and students to create a non-threatening atmosphere in class? What is the ideal extent of the friendliness between students and teachers? 


\section{Results}

The data were analyzed using descriptive statistics, and correlational and factor analytical methods with SPSS.10 for Windows in order establish 1) dimensions/clusters underlying motivation factors, 2) scale reliability, 3) level of endorsement of views on the items and 4) interrelationship of the observed dimensions. Following Clement, et al. (1994), Exploratory Factorial Analysis (EFA) is used to provide a tool for consolidating variables and for generating hypotheses about underlying processes. As noted earlier, this study is not an attempt at replicating previous research nor is it trying to test a hypothesis. Therefore, EFA was carried out to describe and summarize the data, by grouping together variables that correlate, and to reduce the number of items to smaller sets of factors underlying psychological constructs (Tabachnik and Fidell 1996).

The ratio of sample size (363 participants) to items was large enough to warrant principal components analysis (Tabachnik and Fidell 1996). Cronbach is used for examining reliability for each construct while Means (M) and Standard Deviations (SD) are accepted as measures of endorsement and uniformity for individual items as well as constructs.

Since the Pearson Product-Moment correlation matrix (correlations of an item to other items) indicated considerable number of correlations exceeding 0.125 at the $5 \%$ level of statistical significance for this size of population, it was deemed suitable for factoring. Principal component analysis with Oblimin rotation produced a five-factor solution. Oblimin rotation was preferred because it was assumed that the factors underlying the dimensions are related and would correlate with one another. However, some of the items loaded onto more than two factors making it difficult to interpret the data. Therefore, a Varimax rotation was sought, which produced a five factor solution. The application of the Scree Plot confirmed the five factors, which together accounted for $48.1 \%$ of the variance. Loadings lower than 0.32 were suppressed to facilitate the interpretation. All variables included in the test battery loaded onto at least one of the factors.

Inspection of Table 1 shows that Factor 1 receives loadings from four items sharing a common theme of what is expected of the interaction with the teacher in the classroom. This construct requires teachers to be active listeners, to facilitate genuine interaction, and to create interesting, stimulating and meaningful interactions in the classroom. This dimension can best be exemplified by the statement 'The teacher should interact with me, not just ask me to do things for the sake of it.' This factor can be called Genuine Interaction. The reliability is Cronbach $\alpha=0.54$. 
Factor 2 is identified by four items focusing on the empathic features the teacher can bring into classroom. Therefore, this factor can be labeled Empathy (the items that cross-loaded onto two or more factors are included in the index of the factor that they defined most highly, a procedure applied throughout this study.) Empathy factor involves a) the favoring of shy and timid students in an effort to integrate them in class activities by calling them 'my favorite student', b) the caring quality of the teacher, c) the teacher reflecting on his own education and learning difficulties and finally d) asking students in the morning classes if they had breakfast or not. The Cronbach $\alpha$ is 0.51 .

Factor 3 receives loading from two variables, both of which focus on the way a teacher should communicate; body language, gestures, and mimicry as well as expert use of language and intonation, indicating that participants demand actorlike qualities from their teachers. This construct can be called Communication Strategy. The reliability turns out to be Cronbach $\alpha=0.57$.

The fourth factor receives loadings from three items focusing on singling out students for their achievements, their characteristics such as 'naughty', 'clever', etc. and on-the-spot realistic interaction. This dimension can be labeled Student Characteristics following the factor that loaded the most heavily. Participants rejected at Disagreement level (3.84) the comments by teachers on naming successful students while they were happy with calling students 'naughty', 'clever', etc. The alpha is average: 0.55 . Overall, this factor does not seem to be well established in terms of the ideas involved.

\begin{tabular}{|l|c|c|c|c|c|c|c|}
\hline & \multicolumn{5}{|c|}{ Components } & & \\
\hline & 1 & 2 & 3 & 4 & 5 & $\mathrm{M}$ & SD \\
\hline $\begin{array}{l}\text { Item Statements } \\
\text { of it }\end{array}$ & .72 & & & & & 1.46 & .74 \\
\hline 3 Teacher should listen to me attentively & .63 & & & & & 1.23 & .54 \\
\hline $\begin{array}{l}\text { 5 Interesting, stimulating and meaningful } \\
\text { interaction }\end{array}$ & .52 & & & & & 1.28 & .62 \\
\hline $\begin{array}{l}\text { 1 Genuine interaction between T and Ss is } \\
\text { essential }\end{array}$ & .43 & & & & & 1.17 & .42 \\
\hline $\begin{array}{l}\text { 11 Favoring shy students is OK for group } \\
\text { activities }\end{array}$ & & .67 & & & & 2.87 & 1.19 \\
\hline 2 Teachers should care about students & & .62 & & & & 2.28 & 1.09 \\
\hline $\begin{array}{l}\text { 13 Reference to teacher's personal } \\
\text { learning difficulties }\end{array}$ & & .52 & & & & 1.82 & .68 \\
\hline
\end{tabular}




\begin{tabular}{|l|r|r|r|r|r|r|r|}
\hline $\begin{array}{l}12 \text { Teachers can ask me if I had breakfast } \\
\text { or not }\end{array}$ & & .51 & .43 & & & 2.64 & 1.07 \\
\hline $\begin{array}{l}7 \text { Teacher's use of language and } \\
\text { intonation }\end{array}$ & & .74 & & & 1.76 & .74 \\
\hline $\begin{array}{l}\text { 6 Teacher's body language, gestures, and } \\
\text { mimicry }\end{array}$ & & & .72 & & & 1.42 & .58 \\
\hline $\begin{array}{l}\text { 10 Teacher can say things like 'Ali is an } \\
\text { ideal student' }\end{array}$ & & & .72 & & 3.84 & 1.19 \\
\hline $\begin{array}{l}\text { 8 Expressions such as 'naughty' can be } \\
\text { used in class }\end{array}$ & & & & .68 & & 1.30 & .67 \\
\hline $\begin{array}{l}\text { 9 On-the-spot realistic interaction } \\
\text { initiated by T }\end{array}$ & & & & .40 & .35 & 3.07 & 1.07 \\
\hline $\begin{array}{l}\text { 15 I like unpredictable teachers in their } \\
\text { conducting class }\end{array}$ & & & & & .76 & 2.50 & 1.25 \\
\hline $\begin{array}{l}\text { 14 Procedure of lesson should be changed } \\
\text { for variety }\end{array}$ & & & & & .67 & 2.60 & 1.10 \\
\hline Eigenvalues & 2.0 & 1.48 & 1.36 & 1.17 & 1.10 & & \\
\hline Average Item Mean & & & & & & 2.09 & .86 \\
\hline
\end{tabular}

\section{Table 1. Rotated Component Matrix for Interaction}

Finally, Factor 5 receives loadings from two variables both of which focus on the way the lesson is conducted. Here, the first item concerns unpredictability of the teacher in the way she responds to students in order to create variety in the classroom. The second item says that the teacher can break the cycle of implementing the same procedures one after another, and that it is more interesting, and not difficult for students to adapt to a variety of procedures. This dimension can be called Teaching Procedure. Cronbach $\alpha$ is 0.60 .

The second analysis examines the level of endorsement for the examined items as sources of motivation. The total mean for all the variables is 2.09 , a figure very close to Agree while SD is 0.86 , indicating a relatively homogenous response spectrum. The endorsement mean for Genuine Interaction is the highest of all $(\mathrm{M}=1.29)$, followed by Communication Strategy $(\mathrm{M}=1.60)$. The means for Empathy and Teaching Procedure are in between 'Agree' and 'Undecided' $(\mathrm{M}=2.40$ and $\mathrm{M}=2.55)$ whereas the means for Student Characteristics is closer to 'Undecided': $\mathrm{M}=2.73$.

An interesting picture emerges when the means for the constructs are considered in relation to SD's. Genuine Interaction and Communicative Strategy, which have favorable ratings (1.29 and 1.60 respectively), have very low SD'S: both 0.66 , indicating a general agreement across the spectrum. On the other hand, 
less favored constructs, Empathy, Student Characteristics and Teaching Procedure, have very high SD's (1.00, 0.98, and 1.18 respectively), revealing stark differences among participants.

A third analysis concerns the inter-relationship of the identified factors. Moderate associations are observed between the factors. The highest association is between Genuine Interaction and Communication Strategy, followed by that between Communication Strategy and Student Characteristics. No statistically significant relation is observed.

\begin{tabular}{|l|r|r|r|r|r|}
\hline Scales & Genuine Int. & Empathy & Com. Strategy & S. Characteristics & T. Procedure \\
\hline Genuine Int. & 1.000 & & & & \\
\hline Empathy & .042 & 1.000 & & & \\
\hline Com. Strategy & .225 & .110 & 1.000 & & \\
\hline S. Characteristics & .111 & .138 & .172 & 1.000 & \\
\hline T. Procedure & -.013 & .058 & .081 & .169 & 1.000 \\
\hline
\end{tabular}

Table 2. Correlations Between Scales

\section{Discussion and conclusion}

The learners in this study are assumed to have extrinsic (instrumental) motivation, at least given that they are enrolled in a teacher training degree, upon the completion of which they are most likely to have a job. In some sense, what this study tries to do is to complement extrinsic motivation by providing some teacher specific variables in the L2 classroom, which can be considered features of intrinsic motivation. As noted earlier, the components investigated in this study fall within the framework of motivation as conceptualized by Dörnyei (1994) in his quest to come up with a multi-level L2 motivation construct from an educational perspective. The results of this study confirm the existence of Dörnyei's (1994:281-2) course-specific, teacher-specific and group-specific motivational components within The Language Situation Level. Therefore, interaction falls within the teacher-specific component.

Replication studies are needed with a greater number of items in the questionnaire. Further, more examples can be used in the items to give a more transparent picture of what an item is trying to communicate. In addition, item statements could be given in L1 in order 1) to make sure that participants fully understand the content of items, and 2) to help participants process the items quicker to avoid mental fatigue. It would be interesting to research whether young and younger learners react to the phenomena investigated differently from young 
adults. Even though the present study was only exploratory in nature, its findings contribute to an understanding of factors that stimulate student interest in the classroom.

Despite the promotion of numerous materials and strategies, in recent decades, to motivate learners, the teachers' personal strategies still remain a powerful tool to sustain interest in classrooms, including those of tertiary (Chambers 1991; Prabhu 1992). Admitting the significant role of the teacher, this study has examined one way of empowering the teacher in exploring motivational procedures and techniques that she can actually initiate and successfully carry out. It provides evidence relevant to the needs of students. Furthermore, it has shown that the motivational strategies contained within Interaction can be used to contribute to the learning process, as is evident in the self-reported endorsements of these factors by students. The average Mean for endorsing the motivational strategies contained in the questionnaire study stands at a favorable (2,09), meaning that participants Agree with the propositions, as opposed to Strongly Agree and Undecided.

Students have an expectation that they should be treated as any other member of the community regarding care, attention, genuine interaction, and definitely not to be compared with their peers or to be singled out for any characteristic in the classroom. They further expect that teacher's communication in class should include a very good use of language and intonation as well as non-linguistics communication strategies such as body language, gestures and mimicry. Students would like to see the teacher not as mere transmitter of knowledge but as someone to interact with. Interaction should be genuine, interesting and meaningful. Students do not endorse teacher's favoring students (whatever the purpose may be) and getting too personal with teachers.

\section{References}

Chambers, F. 1991. Promoting the use of target language in the classroom. Language Learning Journal 4. 27-31.

Clement, R., Z. Dörnyei \& K.A. Noels. 1994. Motivation, self-confidence, and group cohesion in the foreign language classroom. Language Learning 44. 417448.

Crookes, G., \& Schmidt, R. W. 1991. Motivation: reopening the research agenda.

Language Learning Journal 41. 469-512.

Dörnyei, Z. 1990. Conceptualizing motivation in foreign language learning. Language Learning Journal 40. 45-78.

Dörnyei, Z. 1994. Motivation and motivating in the foreign language classroom. The Modern Language Journal 78. 273-284. 
Gardner, R. C., \& W.E. Lambert. 1972. Attitudes and motivation in second-language learning. Rowley, Mass.: Newbury House Publishers.

Julkunen, K. 1989. Situation and task-specific motivation in foreign language

learning. In Z. Dörnyei and R. Schmidt (eds.) Motivation and second language acquisition 29-42. Manoa: University of Hawai'i.

Morgan, B. 1997. Identity and intonation: linking dynamic processes in an ESL

classroom. TESOL Quarterly 31. 431-450.

Prabhu, N.S. 1992. The dynamics of the language lesson. TESOL Quarterly 26. 225-241.

Prodromou, L. 1991. The good language teacher. English Teaching Forum 29. 2-7.

Rivers, W.M. 1987. Interaction as the key to teaching language for communication. In W.M. Rivers (ed.) Interactive Language Teaching 3-16. Cambridge: Cambridge University Press.

Svanes, B. 1987. Motivation and cultural distance in second language acquisition.

Language Learning Journal 5. 51-73.

Tabachnik, B.G. \& L.S. Fidell. 1996. Using multivariate statistics. New York:

Harper \& Row.

\section{Appendix}

\section{The 15 motivation/attitude variables items}

Items whose score was reversed before summing the variable scores are indicated with a minus sign in brackets.

\section{Part I Interaction}

1. Genuine interaction between teacher and students is essential for a better learning.

2. Teachers don't have to care about students. (-)

3. I would like my teacher to listen to me attentively.

4. Teachers should interact with me, not just ask me to do things for the sake of it.

5. Teacher's activities should stimulate interest in students and create meaningful interactions.

6. Teacher's body language, gestures and mimicry are very important.

7. Teacher's use of language and intonation should reflect teacher's attitude.

8. Teachers can use expressions like "You are very naughty" when necessary.

9. To a late-comer who says "May I come in?", the teacher can say "Ask your friends." to create a genuine interaction.

10. I don't mind if teachers say things like 'Ali is an ideal student'.

11. I don't approve when the teacher calls a shy student his/her 'favorite' student in order to get him/her to participate in class activities. (-)

12. I don't want teachers to ask me if I had breakfast or not. (-)

13. Teachers should sometimes make reference to their learning experiences e.g. learning difficulties.

14. I like it when my teacher is unpredictable in the way he conducts the lesson.

15. Teachers should not change the procedure of the lesson. I find it difficult to adapt. (-) 